\title{
Penguatan Manajemen Melalui Kepatuhan Pelaksanaan Perpajakan
}

\author{
Subadriyah, Jumaiyah, Mahmudatus Sa'diyah \\ Universitas Islam Nahdlatul Ulama Jepara \\ email: subadriyah@unisnu.ac.id
}

Key word:

Management,

Training and

Assistance, Obedient

Tax.

\section{Kata Kunci \\ Manajemen, pelatihan dan pendampingan, taat pajak}

\begin{abstract}
This program of devotion is carried out at the Lembaga Studi Ekonomi dan Kebijakan Publik (LSEKP). This partner is located in the Village of East Jambu RT 08 RW 02, District Mlonggo Jepara. Mitra is a mobile community organization engaged in training activities and discussions to oversee public policy in Jepara. The purpose of science and technology is focused on providing the required tax training by partners. Method of implementing devotion using training and mentoring methods. Training is carried out to all management and members of the institution so that all know the obligation of the implementation of taxation properly. While assistance is given to the chairman of the institution and one member who takes care of administration and taxation. Assistance is done when calculating, preparing, paying and reporting tax obligations. The result of this service activity is: (1) partners are able to calculate, compile, pay and report their tax obligations correctly, (2) partners know sanctions and tax penalties, (3) partners obedient in carrying out tax obligations that is by paying and reporting on time.
\end{abstract}

\begin{abstract}
Abstrak
Program pengabdian ini dilakukan di Lembaga Studi Ekonomi dan Kebijakan Publik (LSEKP). Mitra ini terletak di Desa Jambu Timur RT 08 RW 02, Kecamatan Mlonggo Jepara. Mitra adalah organisasi komunitas bergerak yang terlibat dalam kegiatan pelatihan dan diskusi untuk mengawasi kebijakan publik di Jepara.Tujuan ilmu pengetahuan dan teknologi difokuskan pada penyediaan pelatihan pajak yang dibutuhkan oleh para mitra. Metode penerapan pengabdian menggunakan metode pelatihan dan mentoring. Pelatihan dilakukan untuk semua manajemen dan anggota lembaga sehingga semua tahu kewajiban pelaksanaan perpajakan dengan baik. Sementara bantuan diberikan kepada ketua lembaga dan satu anggota yang mengurus administrasi dan perpajakan. Bantuan dilakukan saat menghitung, mempersiapkan, membayar, dan melaporkan kewajiban pajak.Hasil dari kegiatan layanan ini adalah: (1) mitra dapat menghitung, mengumpulkan, membayar dan melaporkan kewajiban pajak mereka dengan benar, (2) mitra tahu sanksi dan denda pajak, (3) mitra patuh dalam melaksanakan kewajiban pajak yaitu dengan membayar dan melaporkan tepat waktu
\end{abstract}




\section{PENDAHULUAN}

Lembaga Studi Ekonomi dan Kebijakan Publik (LSEKP) didirikan sejak tahun 2015 dengan misi mengawal kebijakan public di Jepara pada khususnya. Lembaga ini beralamat di Desa Jambu Timur RT 08 RW 02 Kecamatan Mlonggo, Kabupaten Jepara. Organisasi non profit ini bergerak dalam kegiatan pelatihan dan diskusi-diskusi guna mengawal kebijakan public yang ada di Jepara. selain itu lembaga ini bertujuan melakukan kegiatan social yang dilaksanakan sengan cara menyisihkan sebagian dana untuk zakat yang akan diberikan pada yang berhak secara langsung tanpa melalui Lembaga Amil Zakat.

Sampai saat ini, LSEKP beranggotakan 32 orang, terdiri dari akademisi, karyawan swasta, pegawai negeri, dan bahkan olahragawan. Diskusi antar anggota dilaksanakan rutin 3 bulan sekali dengan tujuan mangasah pengetahuan dan ketajaman anggota dalam memahami situasi dan kondisi yang terjadi di Jepara pada khususnya. Sedangkan kegiatan lain yaitu kegiatan diskusi dengan pihak ekternal atuapun pelatihan-pelatihan dilaksanakan menyesuaikan dengan situasi dan permintaan pihak eksternal juga.

Dalam melaksanakan aktivitasnya, lembaga ini memiliki berbagai kendala baik dari segi permodalan, administrative maupun pengelolaan organisasinya. Sisi permodalan, saat ini lembaga dijalankan dengan dana yang terkumpul dari anggota. Sehigga, pelaksanaan kegiatan kurang maksimal karena dana yang tersedia terbatas. Dari sisi administrative, lembaga ini juga masih terkendala dengan sumber daya manusia (SDM) yaitu tidak adanya SDM yang khusus focus melakukan kegiatan administrative. Hal ini juga disebabkan kurangnya dana yang tersedia untuk menggaji staf untuk melakukan kegiatan administrasi. Sedangkan dari pengelolaan organisasi, lembaga ini masih sangat sederhana yaitu dengan melakukan rapat koordinasi pada saat akan dilaksanakan sebuah kegiatan. Koordinasi ini untuk membahas kapan dan dimana kegiatan dilaksanakan, siapa saja yang terlibat, berapa anggaran yang diperlukan, serta darimana kekurangan dana dapat tertutupi.

Akses permodalan untuk lembaga sector public semacam lembaga mitra ini adalah adanya donator ataupun investor. Akses ini mengharuskan sebuah proposal yang biasanya dilengkapi dengan laporan pertanggungjawaban dan ketaatan terhadap pajak. Laporan pertanggunjawaban diwujudkan dalam bentuk pelaporan keuangan. Namun, ternyata kedua hal tersebut belum dimiliki oleh mitra pengabdian. Termasuk pelaporan 
perpajakan juga belum terlaksana dengan baik. Hal ini karena ketidakpahaman pengelola lembaga dalam urusan perpajakan.

Hal ini akan menjadi penghambat dalam proses penerimaan donasi dan pertanggungjawaban pada pihak investor maupun sponsor. Karena jika pihak investor atuapun sponsor menginginkan lembaga penerima dana adalah lembaga yang taat pajak, maka lembaga ini terkadang mengalami kendala dalam proses pencairan dananya, yaitu adanya cara pembayaran ataupun pelaporan pajak yang kurang pas sehingga tidak diterima oleh investor.

Berdasarkan uraian diatas, prmasalahan yang dihadapi oleh mitra yaitu Lembaga Studi Ekonomi dan kebijakan Publik (LSEKP) Jepara, yaitu:

1. Kurangnya sumber daya manusia (SDM) dalam pelaksanaan kegiatan adminsitratif, sehingga adminsitrasi lembaga kurang tertata dengan baik.

2. Akses permodalan kurang, salah satu penyebabnya adalah karena lembaga tidak memiliki laporan pertanggunjawaban keuangan serta kurangnya kepatuhan dalam hal perpajakan.

3. Sumber daya manusia (SDM) kurang memahami peraturan perpajakan yang berlaku di Indonesia.
Berdasarkan kondisi tersebut diatas, maka pengabdi dan pengelola, menetapkan permasalahan yang menjadi prioritas untuk diselesaikan dalam program pengabdian ini adalah: Terbatasnya pengetahuan pengelola lembaga dalam pelaksanaan kewajiban perpajakan.

Luaran dari pengabdian ini adalah modul perpajakan, aplikasi perhitungan pajak berbasis Microsoft excel, dan terselengaranya pembayaran dan pelaporan pajak tepat waktu.

\section{MATERI DAN METODOLOGI}

Metode pendekatan yang dilakukan dalam program pengabdian ini adalah melalui pelatihan dan pendampingan dalam pelaksanaan kewajiban perpajakan melalui beberapa tahapan berikut: (1) sosialisasi kepada pengelola dan anggota lembaga tentang kewajiban perpajakan; pelatihan perpajakan khususnya pajak penghasilan kepada seluruh pengelola dan anggota lembaga; (3) pendampingan pelaksanaan kewajiban perpajakan kepada ketua dan salah satu anggota yang bertugas mengurusi pajak; dan (4) evaluasi keberhasilan.

\section{HASIL DAN PEMBAHASAN}

Kegiatan program pengabdian ini dilaksanakan di tempat mitra. Kegiatan pertama yaitu Pelatihan perpajakan diikuti 
oleh pengelola dan anggota lembaga sejumlah 40 orang. Kegiatan pelatihan ini dilaksanakan pada tanggal 27 Juli 2017. Sedangkan kegiatan berikutnya yaitu pendampingan pelaksanaan kewajiban perpajakan, dilaksanakan dengan jadwal tentative sesuai keperluan lembaga dan ketersediaan waktu pengabdi. Kegiatan pendampingan telah dilaksanakan sebanyak 3 kali yaitu pada saat persiapan dan pelaporan pajak bulan April 2017, bulan Mei 2017, dan bulan Juli 2017.

Kegiatan yang pertama adalah pelatihan perpajakan. Dalam pelatihan ini disampaikan beberapa materi dasar yang berkaitan dengan kepatuhan pelaksanaan perpajakan sebagai berikut:

\section{Pajak penghasilan}

Materi pajak penghasilan yang disampaikan mengenai:
a. subjek pajak penghasilan
b. objek pajak penghasilan
c. tarif pajak penghasilan
d. cara menghitung, menyusun, membayar dan melaporkan pajak penghasilan

2. Pajak pertambahan nilai

Seperti halnya materi pajak penghasilan, dalam materi yang disampaikan mengenai pajak pertambahan nilai adalah:
a. subjek pajak penghasilan,
b. objek pajak penghasilan

c. tarif pajak penghasilan

d. cara menghitung, menyusun, membayar dan melaporkan pajak penghasilan

3. Ketentuan umum perpajakan (focus pada sanksi dan denda)

Ketentuan umum perpajakan yang disampaikan disini lebih focus pada peraturan sanksi dan denda yang akan diberikan oleh Direktorat Jenderal Pajak jika wajib pajak tidak melaksanakan kewajiban perpajakan sesuai dengan aturan yang ada.

Dalam kegiatan pelatihan ini juga diberikan contoh-contoh dan latihanlatihan soal untuk lebih memberikan dalam praktek penghitungan pajak.

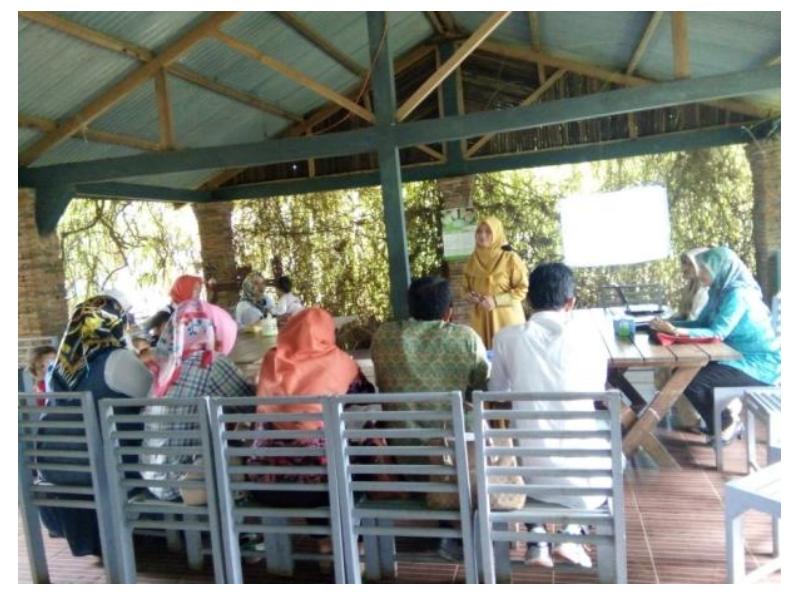

\section{Gambar 1. Pelaksanaan Pelatihan}

Kegiatan pengabdian berikutnya adalah kegiatan pendampingan. Kegiatan ini dilakukan melalui proses pendampingan dengan tahapan: (1) melihat dan memastikan bahwa data yang diperlukan untuk menghitung pajak sudah tersaji 
dengan lengkap, (2) memastikan bahwa identifikasi setiap transaksi yang harus dikenai pajak telah dilaksanakan oleh mitra, (3) memastikan bahwa tarif dan perhitungan pajaknya telah tepat, (4) memastikan formulir yang digunakan ataupun aplikasi online yang digunakan tepat dan telah terisi dengan benar, (5) memastikan bahwa laporan manual telah ditanda tangani dan distempel, (6) memastikan bahwa pembayaran dan pelaporan pajak tepat waktu.

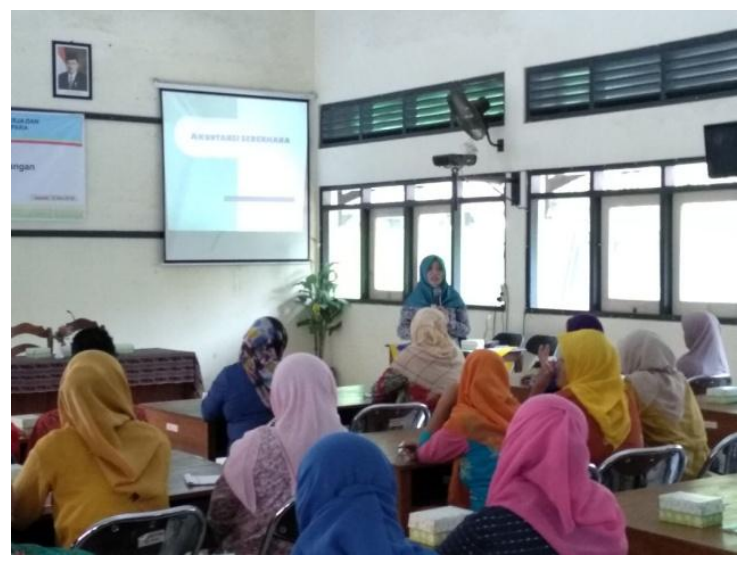

Gambar 2. Pelaksanaan Pendampingan

Kegiatan pengabdian diakhiri dengan adanya pemantauan sejauh mana peserta pelatihan dan pendampingan mampu menerapkan materi yang telah didapat. Evaluasi yang dilakukan tim pengabdi menunjukkan bahwa $80 \%$ peserta mampu melakukan penghitungan pajak.

Tim pengabdi merasa perlu mengevaluasi apakah di tahun selanjutnya, pengabdian yang dilakukan tetap memberikan dampak yang baik dalam hal kemampuan perhitungan pajak dan ketepatan waktu pembayaran pajak.

\section{KESIMPULAN}

Dari kegiatan pengabdian yang telah dilaksanakan maka dapat disimpulkan bahwa: (1) mitra mampu menghitung, menyusun, membayar dan melaporkan kewajiban perpajakannya dengan benar; (2) mitra mengetahui sanksi dan denda perpajakan; dan (3) mitra patuh dalam melaksanakan kewajiban perpajakan yaitu dengan membayar dan melapor tepat waktu.

\section{UCAPAN TERIMAKASIH}

Tim Pelaksana Pengabdian berterima kasih kepada pihak LSEKP yang telah menjadi mitra dalam pelaksanaan pengabdian iniserta pihak terkait lain yang telah membantu selama kegiatan.

\section{REFERENSI}

Putra, Wirmie Eka, dkk. 2016. Upaya Peningkatan Kualitas Laporan Keuangan Pengrajin Resam Melalui Teknologi Informasi Akuntansi. Vol. 31. No.1. Hal 8-10.

Endriani, dkk.2014. Pendampingan

Pengembangan dan Peningkatan Usaha Kerajinan Batik Jambi.Vol. 29 No 4. Hal 17-23. 
Eri Besra, 2012. Potensi Wisata Kuliner

dalam Mendukung Pariwisata Di

Kota Padang.Jurnal Riset Akuntansi

dan Bisnis.Vol.12. No1. Hal 74-

101.

Kastiawan, I Made., Dkk. 2014. Ibm

Kelompok Usaha Rumah Tangga

Aneka Keripik dan Sale Pisang

Desa Wonodadi Kulon.Vol. 01.No.

01. Hal 34-40 